\title{
Prevalence of mutans streptococci in 93 members from six Brazilian families
}

\section{Prevalência de estreptococos do grupo mutans em 93 membros de seis famílias brasileiras}

\author{
Fabiana Cristina PIMENTA* \\ José Moacir MARIN** \\ Milton de UZEDA*** \\ Izabel Yoko ITO**
}

\begin{abstract}
PIMENTA, F. C.; MARIN, J. M; UZEDA, M. de; ITO, I. Y. Prevalence of mutans streptococci in 93 members from six Brazilian families. Pesqui Odontol Bras, v. 15, n. 3, p. 181-186, jul./set. 2001.

Several studies report that mutans streptococci (MS) are closely associated with caries in humans and that there is a correlation between the number of carious lesions and the levels of MS in the saliva of children and adults. The presence of MS in the saliva of 93 members of six Brazilian families with at least 3 generations was investigated. Samples of whole unstimulated saliva were collected and diluted. Aliquots of $50 \mu 1$ of each suspension were dropped onto $\mathrm{SB}_{20}$ agar and incubated in a candle jar at $37^{\circ} \mathrm{C}$ for $72 \mathrm{~h}$. Colonies resembling MS were counted, collected, seeded in thioglycollate medium and subjected to biochemical typing. Mutans streptococci were isolated from 80 subjects $(86.0 \%)$ and the counts ranged from $3.0 \times 10^{2}(\log 2.477)$ to $1.6 \times 10^{8}(\log 8.204) \mathrm{CFU} / \mathrm{ml}$ of saliva. All of the 73 adults were colonized by MS, but the bacteria were detected in only 7 (35.0\%) of the 20 children evaluated. Streptococcus mutans occurred in 78 subjects $(97.5 \%)$, and $51(63.7 \%)$ were monocolonized. S. sobrinus occurred in 29 individuals (36.3\%) and 2 $(2.5 \%)$ were monocolonized. Twenty-seven (33.8\%) subjects were multicolonized with S. mutans and S. sobrinus. This study showed a high prevalence $(86.0 \%)$ of mutans streptococci in the saliva of members of the studied families, which suggests the risk of intrafamilial transmission.
\end{abstract}

UNITERMS: Streptococcus mutans; Family; Saliva; Transmission.

\section{INTRODUCTION}

Mutans streptococci (MS) have been shown to be one of the major causes of dental caries in humans ${ }^{10}$. There is a good correlation between the number of carious lesions and the levels of MS in the saliva of children and adults ${ }^{12}$. Shortly after birth, an oral ecosystem is established, and it consists of different kinds of bacteria. The early establishment of MS in the mouth of children supposably depends on intrafamilial transmission which, in turn, depends on the quantity of these bacteria in the mouth of parents and care-givers ${ }^{3}$.

In epidemiological surveys, the distribution of MS in different populations and families, as well as the fidelity of intrafamilial transmission from mothers to infants have been investigated ${ }^{3,12}$. Several studies reveal a correlation between the levels of Streptococcus mutans in mothers and in their children. They suggest that mothers are the main source of MS to their infants and that their levels of MS may dictate the extent of colonization in their children $^{4}$. However, it is possible that MS derive not only from the mother ${ }^{3}$. EMANUELSSON; WANG $^{6}$ (1998) showed that parents and children of Chinese families had acquired mutans streptococci strains from each other, which was indicated by similar genotypes in some mother-child, father-child as well as father-mother pairs.

Considering the correlation between the prevalence of caries and MS salivary counts, the aim of this study was to evaluate the distribution of MS in the saliva of 93 members of six Brazilian families, from the region of Ribeirão Preto, with at least 3 generations.

\footnotetext{
* Professor, Federal University of Goiás.

** Professors, School of Dentistry of Ribeirão Preto, University of São Paulo.

*** Professor, Institute of Microbiology, Federal University of Rio de Janeiro.
} 
PIMENTA, F. C.; MARIN, J. M; UZEDA, M. de; ITO, I. Y. Prevalence of mutans streptococci in 93 members from six Brazilian families.

Pesqui Odontol Bras, v. 15, n. 3, p. 181-186, jul./set. 2001.

\section{METHODS}

Six families (A, B, C, D, E and F) from the region of Ribeirão Preto, Brazil, were selected for this study. The criterion for selection was the presence of at least 3 generarations. Families A, B and C had, respectively, 11,10 and 8 members, and comprised 4 generations. Families D, E and F comprised 3 generations and had 23, 16 and 25 members, respectively. Whole unstimulated saliva samples from the 93 subjects - 20 children and 73 adults - were collected in a tube with glass beads, mixed for one minute (Mixtron) and submitted to 10 fold dilutions in phosphate buffer saline through $10^{-5}$. Aliquots of $50 \mu \mathrm{l}$ of each dilution were dropped, equidistantly ${ }^{18}$ onto $\mathrm{SB}_{20}$ agar ${ }^{5,15}$ for mutans streptococci $\mathrm{CFU}$ counts. The $\mathrm{SB}_{20}$ agar plates were incubated in a candle jar at $37^{\circ} \mathrm{C}$ for 72 hours. Thereafter, colonies resembling MS were counted, collected, seeded in thioglycollate medium without dextrose and indicator (Difco), and identified $^{14}$. The levels of MS in CFU/ml were converted into logarithms (log).

\section{RESULTS}

A total of $80(86.0 \%)$ family members carried de- tectable salivary levels of mutans streptococci. Table 1 shows the prevalence of MS, S. mutans and $S$. sobrinus in the six families. MS were detected in 7 (35.0\%) of the 20 children, and all infected children were older than 5 years. Table 2 shows the distribution of subjects (percentage) according to their MS salivary levels. The counts of MS (Table 3) ranged from $3.0 \times 10^{2}(\log 2.477)$ to $1.6 \times 10^{8} \mathrm{CFU} / \mathrm{ml}(\log 8.204)$; the counts of S. mutans, from $2.0 \times 10^{2}(\log 2.301)$ to $1.6 \times 10^{8} \mathrm{CFU} / \mathrm{ml}(\log 8.204)$ and those of S. sobrinus, from $6.0 \times 10^{1}(\log 1.788)$ to $5.6 \times 10^{6} \mathrm{CFU} / \mathrm{ml}$ (log 6.748). Streptococcus mutans occurred in 78 subjects $(97.5 \%)$, and 51 $(63.7 \%)$ were monocolonized. S. sobrinus was detected in 29 subjects $(36.3 \%)$, and $2(2.5 \%)$ were monocolonized. Twenty-seven (33.8\%) individuals were multicolonized with $S$. mutans and $S$. sobrinus.

In family A, which had 11 members, MS were isolated from 8 subjects, thus, the prevalence was $72.7 \%$. The counts of MS and S. mutans ranged from $4.0 \times 10^{3}(\log 3.602)$ to $1.65 \times 10^{7} \mathrm{CFU} / \mathrm{ml}$ $(\log 7.217)$. S. mutans was detected in all MS carriers: 7 individuals $(87.5 \%)$ were monocolonized, and only one lodged S. mutans and S. sobrinus.

TABLE 1 - Distribution of the 93 subjects regarding the presence of mutans estreptococci (MS), S. mutans and S. sobrinus in their saliva.

\begin{tabular}{|c|c|c|c|c|c|c|c|c|c|c|c|c|c|c|}
\hline \multirow{2}{*}{ Family } & \multicolumn{2}{|c|}{ A } & \multicolumn{2}{|c|}{ B } & \multicolumn{2}{|c|}{$\mathrm{C}$} & \multicolumn{2}{|c|}{$\mathrm{D}$} & \multicolumn{2}{|c|}{$\mathrm{E}$} & \multicolumn{2}{|c|}{$\mathrm{F}$} & \multicolumn{2}{|c|}{ Total } \\
\hline & $\mathrm{n}$ & $\%$ & $\mathrm{n}$ & $\%$ & $\mathrm{n}$ & $\%$ & $\mathrm{n}$ & $\%$ & $\mathrm{n}$ & $\%$ & $\mathrm{n}$ & $\%$ & $\mathrm{n}$ & $\%$ \\
\hline MS-positive & 8 & 72.7 & 9 & 90.0 & 7 & 87.5 & 22 & 95.7 & 13 & 81.2 & 21 & 84.0 & 80 & 86.0 \\
\hline S. mutans & 7 & 87.5 & 3 & 33.3 & 5 & 71.4 & 8 & 36.4 & 11 & 84.6 & 17 & 81.0 & 51 & 63.7 \\
\hline S. sobrinus & 0 & 0.0 & 1 & 11.1 & 0 & 0.0 & 1 & 4.5 & 0 & 0.0 & 0 & 0.0 & 2 & 2.5 \\
\hline S. mutans + S. sobrinus & 1 & 12.5 & 5 & 55.6 & 2 & 28.6 & 13 & 59.1 & 2 & 15.4 & 4 & 19.0 & 27 & 33.8 \\
\hline Members & 11 & 11.8 & 10 & 10.8 & 8 & 8.6 & 23 & 24.7 & 16 & 17.2 & 25 & 26.9 & 93 & 100 \\
\hline
\end{tabular}

TABLE 2 - Distribution of the 93 subjects regarding the salivary levels of mutans streptococci (MS)*

\begin{tabular}{|c|c|c|c|c|c|c|c|c|c|c|c|c|c|c|}
\hline \multirow{2}{*}{ Family } & \multicolumn{2}{|c|}{ A } & \multicolumn{2}{|c|}{ B } & \multicolumn{2}{|c|}{$\mathrm{C}$} & \multicolumn{2}{|c|}{$\mathrm{D}$} & \multicolumn{2}{|c|}{$\mathrm{E}$} & \multicolumn{2}{|c|}{$\mathrm{F}$} & \multicolumn{2}{|c|}{ Total } \\
\hline & $\mathrm{n}$ & $\%$ & $\mathrm{n}$ & $\%$ & $\mathrm{n}$ & $\%$ & $\mathrm{n}$ & $\%$ & $\mathrm{n}$ & $\%$ & $\mathrm{n}$ & $\%$ & $\mathrm{n}$ & $\%$ \\
\hline $\mathrm{MS}=0$ & 3 & 27.2 & 1 & 10.0 & 1 & 12.5 & 1 & 4.3 & 3 & 18.7 & 4 & 16.0 & 13 & 14.0 \\
\hline $\mathrm{MS}<10^{5}$ & 2 & 18.2 & 0 & 0 & 2 & 25.0 & 8 & 34.8 & 4 & 25.0 & 8 & 32.0 & 24 & 25.8 \\
\hline $\mathrm{MS}=10^{5}$ & 1 & 9.1 & 3 & 30.0 & 3 & 37.5 & 9 & 39.2 & 5 & 31.3 & 6 & 24.0 & 27 & 29.0 \\
\hline $\mathrm{MS} \geq 10^{6}$ & 5 & 45.5 & 6 & 60.0 & 2 & 25.0 & 5 & 21.7 & 4 & 25.0 & 7 & 28.0 & 29 & 31.2 \\
\hline Members & 11 & 11.8 & 10 & 10.8 & 8 & 8.6 & 23 & 24.7 & 16 & 17.2 & 25 & 26.9 & 93 & 100 \\
\hline
\end{tabular}

*Levels of MS in CFU/ml of saliva. 
PIMENTA, F. C.; MARIN, J. M; UZEDA, M. de; ITO, I. Y. Prevalence of mutans streptococci in 93 members from six Brazilian families.

Pesqui Odontol Bras, v. 15, n. 3, p. 181-186, jul./set. 2001.

TABLE 3 - The lowest (L) and highest (H) salivary CFU levels of MS, S. mutans and S. sobrinus in the six Brazilian families.

\begin{tabular}{|c|c|c|c|c|c|c|c|c|c|c|c|c|}
\hline Family & \multicolumn{2}{|c|}{ A } & \multicolumn{2}{|c|}{ B } & \multicolumn{2}{|c|}{$\mathrm{C}$} & \multicolumn{2}{|c|}{$\mathrm{D}$} & \multicolumn{2}{|c|}{$\mathrm{E}$} & \multicolumn{2}{|c|}{$\mathrm{F}$} \\
\hline $\mathrm{CFU}$ & $10^{5}$ & $\log$ & $10^{5}$ & $\log$ & $10^{5}$ & $\log$ & $10^{5}$ & $\log$ & $10^{5}$ & $\log$ & $10^{5}$ & $\log$ \\
\hline L - MS & 0.04 & 3.602 & 4.00 & 5.602 & 0.003 & 2.477 & 0.030 & 3.477 & 0.03 & 3.477 & 0.003 & 2.477 \\
\hline H - MS & 165.00 & 7.217 & $1,600.00$ & 8.204 & 167.000 & 7.223 & 160.000 & 7.204 & 44.00 & 6.643 & 244.000 & 7.387 \\
\hline L - S. mutans & 0.04 & 3.602 & 4.00 & 5.602 & 0.002 & 2.301 & 0.030 & 3.477 & 0.03 & 3.477 & 0.003 & 2.477 \\
\hline H - S. mutans & 165.00 & 7.217 & $1,600.00$ & 8.204 & 167.000 & 7.223 & 157.000 & 7.196 & 44.00 & 6.643 & 200.000 & 7.301 \\
\hline L - S. sobrinus & 3.00 & 5.477 & 0.15 & 4.176 & 0.006 & 1.788 & 0.017 & 3.230 & 3.40 & 5.531 & 0.016 & 3.204 \\
\hline H - S. sobrinus & 3.00 & 5.477 & 56.00 & 6.748 & 0.002 & 2.301 & 23.000 & 6.362 & 5.00 & 5.699 & 44.000 & 6.643 \\
\hline
\end{tabular}

In family B the prevalence of MS was $90.0 \%-$ the bacteria were detected in 9 of the 10 members. MS and S. mutans counts ranged from $4.0 \times 10^{5}$ $(\log 5.602)$ to $1.6 \times 10^{8} \mathrm{CFU} / \mathrm{ml}(\log 8.204)$ and S. sobrinus counts, from $1.5 \times 10^{4}(\log 4.176)$ to $5.6 \times 10^{6} \mathrm{CFU} / \mathrm{ml}(\log 6.748)$. S. mutans was isolated from $8(88.9 \%)$ of the 9 MS-positive subjects and 3 individuals (33.3\%) were monocolonized. One subject (11.1\%) lodged only S. sobrinus. However, 5 subjects $(55.6 \%)$ harbored S. mutans and S. sobrinus.

The prevalence of MS in family C was $87.5 \%$ the bacteria were isolated from $7(87.5 \%)$ of the 8 members. S. mutans was detected in all MS-positive subjects: $5(71.4 \%)$ were monocolonized, and 2 (28.6\%) lodged S. mutans and S. sobrinus. The levels of $S$. mutans ranged from $2.0 \times 10^{2}(\log 2.301)$ to $1.67 \times 10^{7} \mathrm{CFU} / \mathrm{ml}(\log 7.223)$.

In family $\mathrm{D}$, the prevalence of MS was the highest $(95.7 \%)$. Only one $(4.3 \%)$ of the 23 members was free of MS. MS counts ranged from $3.0 \times 10^{3}$ $(\log 3.477)$ to $1.6 \times 10^{7} \mathrm{CFU} / \mathrm{ml}(\log 7.204)$, S. mutans counts, from $3.0 \times 10^{3}(\log 3.477)$ to $1.57 \times 10^{7} \mathrm{CFU} / \mathrm{ml}(\log 7.196)$ and $S$. sobrinus counts, from $1.7 \times 10^{3} \quad(\log 3.230)$ to $2.3 \times 10^{6} \mathrm{CFU} / \mathrm{ml}(\log 6.362)$. S. mutans was isolated from 21 subjects (91.2\%). Eight individuals were (36.4\%) monocolonized, 13 (59.1\%) lodged S. mutans and S. sobrinus and one lodged (4.5\%) only $S$. sobrinus.

The prevalence of MS in family E was $81.2 \%$. MS counts ranged from $3.0 \times 10^{4}(\log 3.477)$ to $4.4 \times 10^{6} \mathrm{CFU} / \mathrm{ml}(\log 6.643)$. MS were isolated from $13(81.2 \%)$ persons: $11(84.6 \%)$ were monocolonized by $S$. mutans and $2(15.4 \%)$ were multicolonized by $S$. mutans and $S$. sobrinus. In this family, a high prevalence of $S$. mutans was observed.

In family $\mathrm{F}$, which had 25 members, the prevalence of MS was $84.0 \%$ (21 individuals), and all MS-positive subjects harbored S. mutans. From those, $4(19.0 \%)$ were multicolonized by $S$. mutans and S. sobrinus. MS counts ranged from $3.0 \times 10^{2}$ $(\log 2.477)$ to $2.44 \times 10^{7} \mathrm{CFU} / \mathrm{ml}(\log 7.387)$.

\section{DISCUSSION}

The association of mutans streptococci with the prevalence of caries has been clearly established in several epidemiological studies ${ }^{10}$. An effective program to prevent or delay the colonization by those microorganisms depends on the identification of the source(s) and mode of transmission of S. mutans from infected to uninfected hosts. Acquisition must occur with great efficiency and within the first decade of life, since virtually all humans are eventually infected with the bacteria ${ }^{3}$. The mother is considered the primary source of MS to her infant, but other members of the family can be associated with the transmission ${ }^{3,6}$.

In this study, mutans streptococci were detected in 80 (73 adults and 7 children) of the 93 subjects, so that the incidence of MS was $86.0 \%$ (Table 1). The highest incidence of MS was detected in family D (95.7\%) and the lowest, in family A (72.7\%). All analyzed adults were colonized by MS. Notwithstanding the differences between the studied populations, this prevalence is similar to the results presented by GÁBRIS et al. ${ }^{7}$ (1999), who detected, among adolescents, a ratio of $89.7 \%$ of MS carriers.

Eighteen adults wore dentures and $66.7 \%$ of them showed MS levels equal or higher than $10^{6} \mathrm{CFU} / \mathrm{ml}(\log 6.0)$. These high levels of MS de- 
PIMENTA, F. C.; MARIN, J. M; UZEDA, M. de; ITO, I. Y. Prevalence of mutans streptococci in 93 members from six Brazilian families.

Pesqui Odontol Bras, v. 15, n. 3, p. 181-186, jul./set. 2001.

tected in adults wearing dentures are in accordance with the results of SALONEN et al..$^{13}$ (1990), who studied, in an adult Swedish population, the distribution of mutans streptococci among dentate adults wearing and not wearing any kind of removable denture. The distribution of MS among dentate adults not wearing any kind of removable denture was similar to that previously reported in studies on Swedish schoolchildren, while a higher fraction of subjects with high levels of mutans streptococci was found among the individuals who wore some kind of removable denture.

PACKER et al. ${ }^{11}$ (1999) analyzed the correlation between the MS salivary levels of 50 care-givers and those of their children. They detected MS in all children and adults, and $76.0 \%$ and $85.0 \%$, respectively, harbored MS levels equal to or higher than $10^{6} \mathrm{CFU} / \mathrm{ml}$ in their saliva. Those authors showed that there was high similarity $(73.0 \%)$ between the salivary levels of MS of care-givers and those of their children.

MS were not detected in $13(65.0 \%)$ of the 20 children, and all of the MS-negative children were younger than 5 years old. ALALUUSUA et al. ${ }^{1}$ (1994) showed that the level of Streptococcus mutans infection in a group of 5-year-old children was low; only $6 \%$ of the children had high levels of the bacteria. GRINDEFJORD et al. ${ }^{8}$ (1991) analyzed the prevalence of mutans streptococci in 1,095 1-year-old children and detected that only $6 \%$ of the subjects were colonized. The percentage of $35.0 \%$ of children colonization found in this research is similar to that reported by BERKOWITZ et al. ${ }^{2}$ (1981), who detected S. mutans in $38(24.4 \%)$ of 156 infants analyzed.

The salivary levels of MS (Tables 2 and 3) ranged from $3.0 \times 10^{2} \quad(\log 2.477)$ to $1.6 \times 10^{8} \mathrm{CFU} / \mathrm{ml}(\log 8.204)$. It was observed that 24 subjects $(25.8 \%)$ harbored less than $10^{5}$ (log 5.0) CFU of MS, 27 subjects (29.0\%) harbored $10^{5}$ $(\log 5.0)$ and, in 29 individuals $(31.2 \%)$, the MS salivary levels were equal or higher than $10^{6}(\log 6.0)$. BERKOWITZ et al. ${ }^{2}$ (1981) analyzed 156 motherinfant pairs. S. mutans was detected in 38 (24.4\%) of the 156 infants. The mean salivary level of S. mutans in 38 mothers of infected infants was $1.16 \times 10^{6} \mathrm{CFU} / \mathrm{ml}$. In contrast, the mean salivary level of $S$. mutans in 118 mothers of noninfected infants was $2.03 \times 10^{5} \mathrm{CFU} / \mathrm{ml}$. Those autors showed the relationship between maternal salivary levels of $S$. mutans and the risk for the infection of infants. The percentage of infected infants was $58.0 \%$ when maternal salivary levels exceeded $10^{5}$ $\mathrm{CFU} / \mathrm{ml}$. On the other hand, the frequency of infected infants was $6.5 \%$ when maternal salivary levels were lower than or equal to $10^{3} \mathrm{CFU} / \mathrm{ml}$. Those observations indicated that the risk of infection was approximately nine times greater for the children of mothers whose MS levels were equal to or higher than $10^{6} \mathrm{CFU} / \mathrm{ml}$. In this study, 29 adults $(31.2 \%)$ showed MS levels equal to or higher than $10^{6} \mathrm{CFU} / \mathrm{ml}(\log 6.0)$, which represents a great risk for the infection of children.

VAN HOUTE et al. ${ }^{17}$ (1981) studied 85 caries-free children and 67 children who presented with caries, as well as most of their parents. S. mutans was detected in $59.0 \%$ of the caries-free children and in $96.0 \%$ of the children who presented with caries. The detection of $S$. mutans in the mothers of caries-free children $(62.0 \%)$ was also significantly lower than that of either the fathers $(92.0 \%)$ or mothers $(100.0 \%)$ of children who presented with caries. The salivary levels of MS were higher in the mothers of children who presented with caries $\left(1.7 \times 10^{5} \mathrm{CFU} / \mathrm{ml}\right)$ than in the mothers of caries-free children $\left(9.2 \times 10^{4} \mathrm{CFU} / \mathrm{ml}\right)$. These observations lend further support to the existence of familial factors related to the oral levels of $S$. mutans. The percentage of adult MS carriers (100.0\%) found in this research is consistent with the results of TORRES et al. ${ }^{16}$ (1999), who studied the oral status of 50 pregnant women. Mutans streptococci were detected in $48(96.0 \%)$ saliva samples. From those, $4(8.0 \%)$ had an infection level of $1.0 \times 10^{4} \mathrm{CFU} / \mathrm{ml}$, $10(20.0 \%), 5.0 \times 10^{4} \mathrm{CFU} / \mathrm{ml}$, and $4(8.0 \%)$, $1.0 \times 10^{5} \mathrm{CFU} / \mathrm{ml}$. Levels of infection considered more favorable for transmission were found in 30 $(60.0 \%)$ pregnant women: $10(20.0 \%)$ presented with $2.5 \times 10^{5} \mathrm{CFU} / \mathrm{ml}, 12 \quad(24.0 \%)$, with $5.0 \times 10^{5} \mathrm{CFU} / \mathrm{ml}$ and $8 \quad(16.0 \%)$, with $1.0 \times 10^{6} \mathrm{CFU} / \mathrm{ml}$. The results indicated that there are many pregnant women harboring high levels of mutans streptococci, which is considered a risk for the transmission of those microorganisms to infants.

In family B, a similar prevalence of $S$. mutans and $S$. sobrinus, as well as the highest salivary levels of MS were observed. The highest level of MS $1.6 \times 10^{8} \mathrm{CFU} / \mathrm{ml}(\log 8.204)$ - was detected in the grand-father, who was a denture wearer. Family $\mathrm{C}$ showed the lowest MS salivary levels (Table 3).

The predominance of Streptococcus mutans in families A, C, E and F was detected. In families B 
PIMENTA, F. C.; MARIN, J. M; UZEDA, M. de; ITO, I. Y. Prevalence of mutans streptococci in 93 members from six Brazilian families.

Pesqui Odontol Bras, v. 15, n. 3, p. 181-186, jul./set. 2001.

and D, a similar prevalence of Streptococcus mutans and Streptococcus sobrinus was noticed (Table 1). The highest prevalence of $S$. sobrinus was observed in families B and D, in which 5 (55.6\%) and $13(59.1 \%)$ subjects, respectively, lodged S. sobrinus along with $S$. mutans. Another interesting observation in these two families was the detection of a $S$. sobrinus monocolonized adult in each one of them. S. sobrinus has been described as more virulent than $S$. mutans due to the production of acids with lower energetic consumption ${ }^{10}$.

In family $B$, the highest prevalence of S. sobrinus and the highest levels of MS were detected $-1.6 \times 10^{8} \mathrm{CFU} / \mathrm{ml}(\log 8.204)-$; all subjects showed levels of MS equal to or higher than $10^{5}$ CFU (Table 2).

CAUFIELD et al. ${ }^{4}$ (1988) showed that the levels of mutans streptococci in the saliva of mothers correlate significantly with the levels found in their children. This correlation suggests, among other possibilities, that there is a quantitative relationship between the levels of mutans streptococci in mothers and in their children. The prevalence of MS in the families evaluated in this study was high $(86.0 \%)$, which is a risk for the infection of children. KÖHLER; ANDREEN ${ }^{9}$ (1994) showed that the reduction of the levels of mutans streptococci in the saliva of mothers during the eruption of the primary teeth in their children has a long-term influence in the colonization by these bacteria and in the caries experience of children. So, in order to arrest the development of caries, it is important to perform restorative dental care as well to carry out preventive measures which reduce the salivary levels of mutans streptococci in parents and other family members, thus delaying the colonization of children.

In the next step of this research, the similarity between MS strains isolated in each family will be studied in order to demonstrate intrafamilial transmission.

\section{CONCLUSIONS}

1. Mutans streptococci were detected in 80 $(86.0 \%)$ of the 93 subjects from six Brazilian families;

2. Streptococcus mutans were isolated from 78 $(97.5 \%)$ subjects and S. sobrinus, from 29 (36.3\%); furthermore, $51(63.7 \%)$ and $2(2.5 \%)$ persons were monocolonized by $S$. mutans and S. sobrinus, respectively;

3. Twenty-seven members (33.8\%) were multicolonizated by $S$. mutans and S. sobrinus;

4. Salivary MS levels ranged from $3.0 \times 10^{2}$ $(\log 2.477)$ to $1.6 \times 10^{8} \mathrm{CFU} / \mathrm{ml}(\log 8.204)$; the levels of $S$. mutans, from $2.0 \times 10^{2}(\log 2.301)$ to $1.6 \times 10^{8} \mathrm{CFU} / \mathrm{ml}(\log 8.204)$, and those of S. sobrinus, from $6.0 \times 10^{1}(\log 1.788)$ to $5.6 \times 10^{6} \mathrm{CFU} / \mathrm{ml}(\log 6.748)$;

5. The prevalence of MS in families A, B, C, D, E and $\mathrm{F}$ were $72.7 ; 90.0 ; 87.5 ; 95.7 ; 81.2$ and $84.0 \%$, respectively;

6 . The prevalence of MS in the members of six Brazilian families $(86.0 \%)$ can be considered high and suggests intrafamilial transmission.

PIMENTA, F. C.; MARIN, J. M; UZEDA, M. de; ITO, I. Y. Prevalência de estreptococos do grupo mutans em 93 membros de seis famílias brasileiras. Pesqui Odontol Bras, v. 15, n. 3, p. 181-186, jul./set. 2001.

Vários estudos relatam que os estreptococos do grupo mutans (SGM) estão associados à cárie e que existe uma correlação entre o número de lesões de cárie e de SGM na saliva de crianças e adultos. Foi avaliada a presença de SGM na saliva de 93 membros de seis famílias brasileiras com no mínimo três gerações. Amostras de saliva não estimulada foram coletadas e diluídas. Alíquotas de $50 \mu 1$ de cada suspensão foram gotejadas em ágar $\mathrm{SB}_{20}$ e incubadas em jarras de anaerobiose a $37^{\circ} \mathrm{C}$ por 72 horas. As colônias com características de SGM foram contadas e repicadas em caldo tioglicolato e submetidas a biotipagem. Os estreptococos do grupo mutans foram isolados de $80(86,0 \%)$ membros e as contagens na saliva variaram de $3,0 \times 10^{2}(\log 2,477)$ a $1,6 \times 10^{8}(\log 8,204) \mathrm{CFU} / \mathrm{ml}$. Todos os 73 adultos estavam colonizados com SGM, mas a bactéria foi detectada apenas em $7(35,0 \%)$ das 20 crianças. Streptococcus mutans foi identificado em 78 (97,5\%) individuos, e 51 (63,7\%) eram monocolonizados. S. sobrinus foi isolado de 29 (36,3\%) membros e $2(2,5 \%)$ estavam monocolonizados. Vinte e sete $(33,8 \%)$ indivíduos estavam multicolonizados com S. mutans e $S$. sobrinus. O estudo mostrou uma elevada prevalência $(86,0 \%)$ de estreptococos do grupo mutans na saliva dos membros das famílias sugerindo o risco de transmissão intrafamilial.

UNITERMOS: Streptococcus mutans; Familia; Saliva; Transmissão. 
PIMENTA, F. C.; MARIN, J. M; UZEDA, M. de; ITO, I. Y. Prevalence of mutans streptococci in 93 members from six Brazilian families.

Pesqui Odontol Bras, v. 15, n. 3, p. 181-186, jul./set. 2001.

\section{BIBLIOGRAPHIC REFERENCES}

1. ALALUUSUA, S.; MYLLÄRNIEME, S.; KALLIO, M. Streptococcus mutans infection level and caries in a group of 5-year-old children. Caries Res, v. 23, n. 3, p. 190-194, 1989.

2. BERKOWITZ, R. J.; TURNER, J.; GREEN, P. Salivary levels of Streptococcus mutans and primary oral infection of infants. Arch Oral Biol, v. 26, n. 8, p. 147-149, 1981.

3. CAUFIELD, P. W. Dental caries - a transmissible and infectious disease revisited: a position paper. Pediatr Dent, v. 19, p. 491-498, 1997.

4. CAUfIELD, P. W.; RATANAPRIDAKUL, K.; ALLEN, D. N.; CUTTER, G. Plasmid-containing strains of Streptococcus mutans cluster within family and radical cohorts: implications for natural transmission. Infect Immun, v. 56, n. 12, p. 3216-3220, 1988.

5. DAVEY, A. L.; ROGERS, A. H. Multiple types of the bacterium Streptococcus mutans in the human mouth and their inter-familial transmission. Arch Oral Biol, v. 29, n. 6, p. $453-460,1984$.

6. EMANUELSSON, I. M. R.; WANG, X. Demonstration of identical strains of mutans streptococci within Chinese families by genotyping. Eur J Oral Sci, v. 106, p. 788-794, 1998.

7. GÁBRIS, K.; NAGY, G.; MADLÉNA, M. et al. Associations between microbiological and salivary caries activity tests and caries experience in Hungarian adolescents. Caries Res, v. 33, n. 3, p. 191-195, 1999.

8. GRINDEFJORD, M.; DAHLLÖF, G.; WILKNA, S. et al. Prevalence of mutans streptococci in one-year-old children. Oral Microbiol Immun, v. 6, n. 5, p. 280-283, 1991.

9. KÖHLER, B.; ANDREEN, I. Influence of caries-preventive measures in mothers on cariogenic bacteria and caries experience in their children. Arch Oral Biol, v. 39, n. 10, p. 907-911, 1994.

10. LOESCHE, W. J. Cárie dental: uma infecção tratável. 3. ed. Rio de Janeiro : Cultura Médica, 1993. 41 p.

11. PACKER, B. N.; VALENT, P. H. M.; BRETZ, W. A. Avaliação de fatores relacionados à transmissão de infecções pelos estreptococos do grupo mutans. Rev ABO Nac, v. 7, n. 10, p. 108-113, 1999.

12. REICH, E.; LUSSI, A.; NEWBRUN, E. Caries risk assessment. Int Dent J, v. 49, n. 1, p. 15-26, 1999.

13. SALONEN, L.; ALLANDER, L.; BRATTHALL, D.; HELLDEN, L. Mutans streptococci, oral hygiene, and caries in an adult Swedish population. J Dent Res, v. 69, p. 1469-1475, 1990.

14. SHKLAIR, I. L.; KEENE, H. J. A biochemical scheme for the separation of the five varieties of Streptococcus mutans. Arch Oral Biol, v. 23, n. 11, p. 361-366, 1978.

15. TORRES, A. S.; PIZZOLITTO, A. O.; ELLIAS, A. M.; ITO, I. Y. Estreptococos do grupo mutans: avaliação do ágar $\mathrm{SB}_{20}$ e MSB na determinação de UFC na saliva e na placa dental de adolescentes. Rev Bras Odontol, v. 50, n. 6, p. 18-21, 1993.

16. TORRES, A. S.; ROSA, O. P. S.; AKIYOSHI, N. et al. Infection levels in pregnant women by mutans streptococci. Rev Odontol Univ São Paulo, v. 13, n. 6, p. 225-231,1999.

17. van HOUTE, J.; YANOVER, L.; BRECHER, S. Relationship of levels of the bacterium Streptococcus mutans in saliva of children and their parents. Arch Oral Biol, v. 26, n. 1, p. 38-46, 1981.

18. WESTERGREN, G.; KRASSE, B. Evaluation of a micromethod for determination of Streptococcus mutans and Lactobacillus infection. J Clin Microbiol, v. 7, n. 1, p. $82-83,1978$.

Recebido para publicação em 14/08/00 Enviado para reformulação em 13/03/01 Aceito para publicação em 04/06/01 